\title{
IDENTIFICATION OF WET AREAS IN AGRICULTURAL LANDS USING REMOTE SENSING DATA
}

\author{
Toms Stals, Janis Ivanovs \\ Latvian State Forest Research Institute 'Silava', Latvia \\ toms.stals@silava.lv
}

\begin{abstract}
Wet areas in agricultural lands are usually not fully or properly managed due to problematic accessibility by heavy machinery and are associated with lower crop yields. There are neither studies regarding spatial distribution of wet agricultural areas in Latvia nor large scale soil maps. Being aware of these wet areas, it would be possible to plan actions for effective management of these areas, starting with a scale of landscape. A geographic information system model could serve as an assistant for decision-making, such as, a direct support for the management of amelioration systems, change of land use and management patterns or granting support payments.

Remote sensing data like Sentinel-2 satellite images and LiDAR (Light detecting and ranging) technology can be used to identify local wet areas. The focus of this article is to evaluate different remote sensing indices and methods that can be used to identify wet areas in agricultural lands using open access data and software. From 52 indices, which were analysed with soil moisture field measurements in 33 sample plots, only two of them showed statistical significance in linear regression model $(\mathrm{p}<0.05)$ : normalized height model in resolution of 25 meters $\left(\mathrm{r}^{2}=0.45\right)$ and visible blue spectral band in April $\left(\mathrm{r}^{2}=0.39\right)$. Results from this study help to focus on different aspects of remote sensing data usage and methodology for future improvements in order to fully implement LiDAR and Sentinel-2 data for identification of wet areas in agricultural lands.
\end{abstract}

Key words: Remote Sensing, GIS, LiDAR, Sentinel-2, agricultural lands.

\section{Introduction}

Last 50 years have marked significant increase in food growing and production, also in human population, which is predicted to be about 9 billion people in the middle of this century, but the limit is reached where, on global scale, agricultural lands could be expanded at the same rate as demand for the food. This situation leads to a question: how to sustainably produce the amount of food needed (Godfray et al., 2010; Tilman et al., 2002)? H. Godfray and M. Tester highlights in their studies that the best way to address future challenges in agriculture globally is a proper way of land use and management locally, while the knowledge of both farmers and policy makers is one of the key factors (Godfray et al., 2010; Tester \& Langridge, 2010).

Soil is one of the most important resources in agriculture - it provides plants with water and nutrients, serves as a habitat for organisms and a place for water storage, supply and purification (Mitchell $\&$ Soga, 2005). Wet and poorly drained soils are important for biodiversity (Plantureux, Peeters, \& McCracken, 2005), but also are one of the limiting factors to efficiently manage agricultural lands, forests and similar fields (Pearsall, 1950). Information about these areas and their spatial distribution helps to improve the quality of land management and to avoid operational problems, negative environmental impact and additional financial costs (Christensen et al., 1996). Soil science has been widely studied in Latvia, soil classification system has been developed, many books published and agricultural lands mapped in the Soviet times, but there is neither actual information and comprehensive materials on the spatial distribution of soil moisture in Latvia nor large-scale soil maps (Kasparinskis \& Kārklinš̌, 2018).

As technologies develop, more and more new data sources are used in soil studies. Various remote sensing tools, such as terrain models from laser scanning data, multi-spectrum satellite images, specific modelling tools and hydrological models are used for soil spatial modelling and condition determination worldwide (Minasny \& McBratney, 2016). The hydrological conditions may be influenced by many factors and their interaction, but one of the most important factor is the surface topography - both groundwater and surface water flows almost always coincide with the direction and steepness of the slope, following potential energy of gravity of the Earth (Burt \& Butcher, 1986; Zinko et al., 2005).

The LiDAR (Light Detecting and Ranging), technology rapidly evolving nowadays, provides more and more possibilities for analysing an area or a study object. LiDAR is similar to a radar, only pulsing light signals are emitted and detected instead of radio waves (Schwarz, 2010). Laser scanning can be performed from different type of machinery, both from airborne (aircrafts, drones, etc.) and terrestrial (cars, rovers, stands, etc.), but almost all of the LiDAR system consists of four main components: a laser, scanner and optics, photodetector, and navigation and positioning system. The operating principle is simple - a laser beam is transmitted to a reflecting surface and the receiving equipment measures the time it returns to the source, in combination with the GPS receiver and the IMU sensor, it is possible to determine the exact relative distance (reflection point) for each light beam (Bellian et al., 2004). LiDAR 


\section{Characteristics of study sites}

\begin{tabular}{|l|c|c|c|l|}
\hline \multicolumn{1}{|c|}{ Name } & Coordinates & Area (ha) & Sample plots & \multicolumn{1}{c|}{ Description of wet conditions } \\
\hline Skriveri1 & $\begin{array}{l}56.691385, \\
25.137438\end{array}$ & 17.6 & 9 & $\begin{array}{l}\text { In terrain depressions water accumulates seasonally, in two } \\
\text { separate wet areas land is not managed }\end{array}$ \\
\hline Skriveri2 & $\begin{array}{l}56.694682, \\
25.144385\end{array}$ & 7.2 & 6 & $\begin{array}{l}\text { In terrain depression water accumulates on a long-term } \\
\text { basis, land management is difficult (ploughing) }\end{array}$ \\
\hline Skriveri3 & $\begin{array}{l}56.696242, \\
25.129931\end{array}$ & 20.2 & 6 & $\begin{array}{l}\text { In terrain depression water accumulates on a long-term } \\
\text { basis, land management is difficult (ploughing) }\end{array}$ \\
\hline Pure1 & $\begin{array}{l}57.041472, \\
22.913811\end{array}$ & 6.7 & 6 & $\begin{array}{l}\text { In terrain depression water accumulates seasonally, in wet } \\
\text { area land is not managed }\end{array}$ \\
\hline Pure2 & $\begin{array}{l}57.043572, \\
22.882180\end{array}$ & 5.8 & 6 & $\begin{array}{l}\text { In the river valley water accumulates seasonally, land } \\
\text { management is difficult (mowing) }\end{array}$ \\
\hline Stende & $\begin{array}{l}57.210798, \\
22.559618\end{array}$ & 2.1 & 6 & $\begin{array}{l}\text { In whole area water accumulates on a long-term basis, land } \\
\text { is not managed, partially created drainage system }\end{array}$ \\
\hline
\end{tabular}

technology can provide several thousand individual measurements every second, but the number of measurements and their accuracy vary depending on performance and technical parameters of each component. The more accurate and denser the point cloud, the higher quality of the output data and the postprocessing capabilities, but for the user it also means higher costs for the equipment, so it is important to choose the appropriate technical specifications for the intended purpose (Dassot et al., 2011). The accuracy of high-resolution data in the lower layers can also be significantly affected by vegetation density and swelling, which can hold most laser beams to from reaching ground surface (Moskal et al., 2009).

Similar to LiDAR, another evolving and modern remote sensing data type is multispectral imagery from Sentinel-2 satellites. The main advantage of the use of satellites is temporal resolution, as scenes are available relatively often and long-term monitoring of the site is possible (Alparone et al., 2004). Optical satellite sensors capture the electromagnetic beams of the Sun reflected from the Earth's surface within the range of visible light and infrared light, mostly panchromatic, black-and-white or multispectral scenes, producing coloured images from combination of different wavelengths (Deilami \& Hashim, 2011). The Sentinel-2 program consists of 2 multispectral satellites operating at the time. Their orbits are synchronized with the movement of the Sun relative to Earth, thereby achieving repeated satellite overflights relative to specific points on Earth at the same time of the day. Such an orbit is essential for reading long-term and constant measurements. The images of different spectral channels are available within a resolution of 10, 20 and 60 meters. The visible lights and closerange infrared scenes are available at a resolution of 10 meters (Drusch et al., 2012).

The aim of this study is to evaluate different indicators from LiDAR point clouds and Sentinel-2 multispectral images using GIS algorithms to process raw data and obtain comparable values to the field data.

\section{Materials and Methods}

The study was conducted at six sites in the central part of Latvia, where LiDAR data was available in the year 2018. Study sites were selected according to the survey of the owners where some of the area, seasonally or long-term, is difficult for the land management due to wet conditions or water accumulation. For field work, the boundaries of the study sites were marked by the natural and rural block boundaries, where each site includes both an area with optimal water regime for agriculture and wet area where the land management is difficult. For each optimal and wet area 3 random points were generated, making in total 39 sampling plots (Table 1).

Field Measurements were collected in November 2018. Each sample point was probed with a soil probe (with a maximum depth of $115 \mathrm{~cm}$ and the following indicators were identified: an occurrence and depth of reductimorphic colours, depth of groundwater (if reached) and granulometric composition for comparison with old (USSR) soil maps. In addition, soil moisture was measured with Eijelkamp Penetrologger ThetaProbe over a two-day period, under similar weather conditions (cloudy days without rain), so that no rapid changes in soil moisture could happen and data would be comparable (Vereecken et al., 2008). Later on, soil sub-type after Taxonomy of Latvia soils was determined (Kārkliņš et al., 2009) and various indices from cartographic materials were defined: soil granulometric composition and sub-type from old soil maps (40 years and older); quaternary sediments and density of an amelioration network.

LiDAR point cloud data for this study is acquired from Latvian Geospatial Information Agency with a minimum point density at least 1.5 points per $\mathrm{m}^{2}$, 
average horizontal point error is 0.36 meters and vertical accuracy 0.12 meters. Each point cloud data covers $1 \mathrm{~km}^{2}$ wide area and is already pre-classified. For each study site digital elevation models (DEM) were created from 4 to 12 raw data cells (1-2 central cell containing study area and buffer zone) for precise hydrological runoff modelling. Digital elevation model was created in GRASS GIS 7.4.2 application where point clouds in .las format were imported (using only ground surface class from point cloud data), empty cells filled with r.fillnulls tool (using bicubic method), point clouds were merged with r.patch tool and DEM was exported in 2, 5, 10 and 25 meter resolutions in GTiff format for further processing in QGIS 3.4.3. In addition, DEM with a resolution of 2 meters was processed in WhiteboxGIS 3.4 where with a tool Burn Streams at Roads ditches were smoothened for regular stream network (simulating culverts under the roads). In QGIS, a digital elevation model in all resolutions was processed with several SAGA GIS tools. Using a Relative heights and slope tool a normalized height model was made, which shows differences in local topography (Böhner \& Selige, 2006) more clearly. Terrain depressions were filled with a Fill sinks tool (a raster map of depression depth was generated by extracting original DEM from filled), the depression map shows areas in the terrain where water could accumulate (Wang \& Liu, 2006). Using a Slope, Aspect, Curvature tool steepness of the slope was calculated. As a slope of the surface increases, the risk of water accumulation decreases, but water accumulation increases at the bottom of the slope, especially if a negative relief is formed on which the water flows from the surrounding area (Beven \& Germann, 1982). The catchment area (with Catchment area tool) shows the size of the area from which each cell receives surface water runoff, which allows to distinguish smooth water flows in the terrain model from the highest to the lowest point (O'Callaghan \& Mark, 1984). Using SAGA Wetness Index and Topographic Wetness Index (TWI) tools two wetness indexes were modelled. As the end result of both models are indexes without set values, a Raster normalization tool (in a scale 1 to 10) was used for comparison both models and study areas. TWI in different studies have shown good results to determine moisture conditions in different areas, but it is not suited for flat areas and resolutions of digital elevation model higher than 25 meters (Case et al., 2005; Sørensen \& Seibert, 2007). Topographic wetness index simulates the water flow as a thin layer moving from cell to cell, whereas SAGA index algorithms focus on the vertical cell distances relative to adjacent water objects and streams (Böhner et al., 2001).

Sentinel-2 multispectral imagery data for this study is acquired from European Space Agency using all available bands at best spatial resolution of 10 meters: (B2) visible blue spectral band, (B3) visible green spectral band, (B4) visible red spectral band and (B8) near infrared spectral band (Immitzer, Vuolo, \& Atzberger, 2016). Although imagery from Sentinel-2 is available regularly, most of the scenes are covered with clouds, especially in spring and autumn seasons. Normalized Difference Vegetation Index (NDVI) is calculated from near infrared spectral band (NIR) and visible red spectral band (VIS) mathematically in Formula 1 (Pettorelli et al., 2005):

$$
N D V I=\frac{(N I R-V I S)}{(N I R+V I S)}
$$

To combine processed layers in GIS with field data, a Point sampling tool in QGIS was used for statistics of sample points. In total, 52 indices were generated (32 from LiDAR point clouds and 20 from Sentinel-2 multispectral imagery). The soil moisture measurements (\%) were selected as the best parameter from field work for data comparison. Pearson's correlation coefficient was calculated for each data pair, then the indices with best results were used in a linear regression model for determination of statistical significance in the program R. In addition, all quantitative data was analysed by principal component analysis (PCA) in PC-Ord 5.0.

\section{Results and Discussion}

Among the surveyed 39 sample plots, only in 8 plots soil sub-types today coincide with the USSR soil maps. Results suggest that old soil maps nowadays serve as an approximate informative material. Soil subtype and granulometric composition are influenced by time (soil processes), scale of map and methodology. The main differences between USSR soil maps and the results from field works are the higher proportion of podzolification process and lower soil moisture conditions.

After selecting indices with higher correlation coefficients and statistical significance in a linear regression model $(p<0.05)$ only two of the GIS based parameters show connection between measurements of soil moisture: a normalized height model in resolution of 25 meters $\left(r^{2}=0.45\right)$ and visible blue spectral band in April $\left(r^{2}=0.39\right)$, yet the correlation between data is not high. Normalized height in resolution of 25 meters shows that this is suitable scale to analyse study sites at corresponding areas. The noise of high-resolution data does not interfere, yet local elevations and depressions are still visible and show the best correlation with surveyed wet areas on fields.

Different studies show that from indicators like a slope, SAGA wetness index and NDVI it is possible to get high-quality results for identification soil moisture 


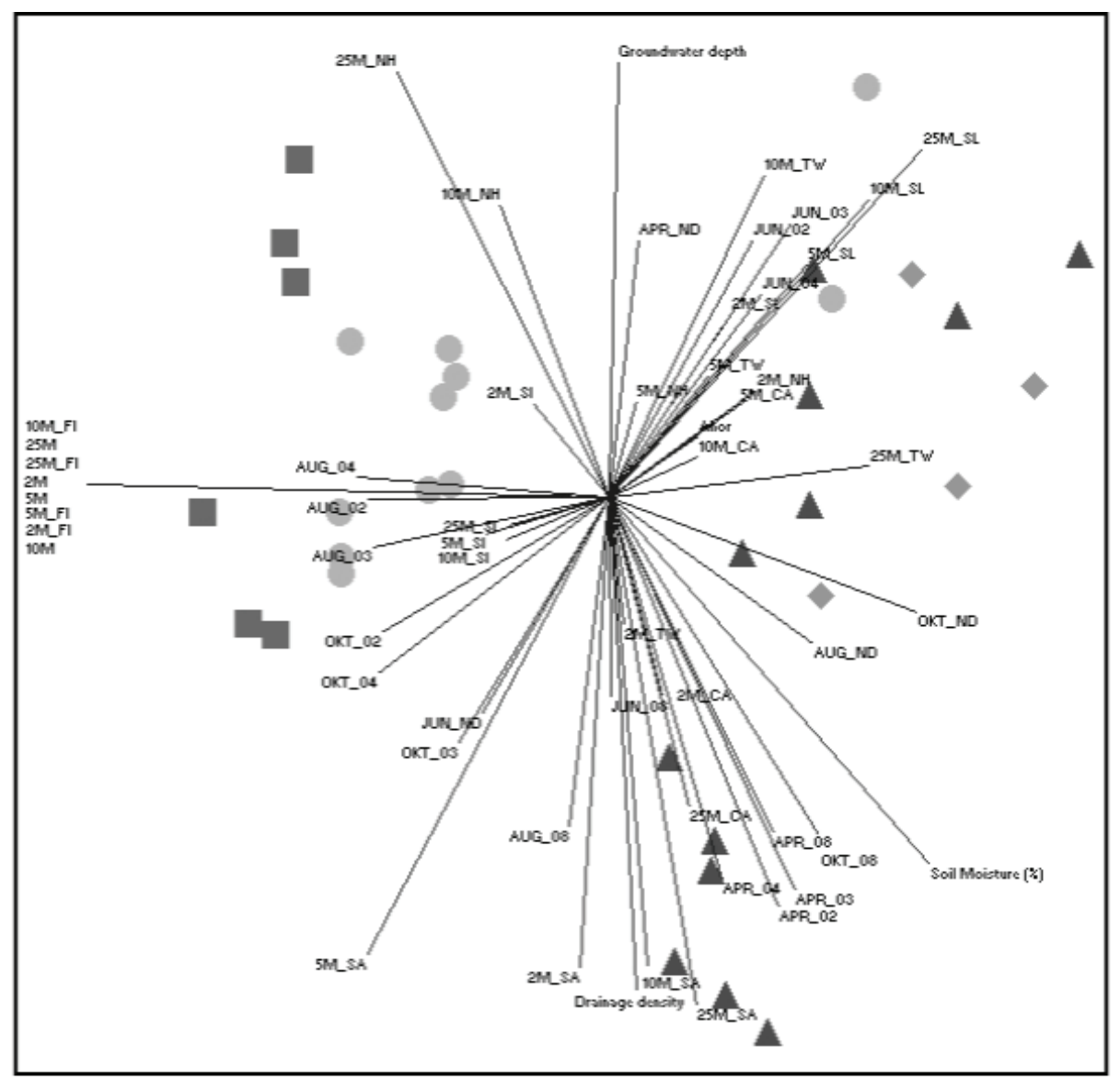

$\Delta$ Unmanaged meadow $>$ Mowed meadow $\odot$ Tree plantation $\square$ Arable land

Figure 1. Quantitative measurements from GIS models and field work in principal component analysis.

in forestry (Ivanovs \& Lupikis, 2018) and agriculture (McCoy, Asner, \& Graves, 2011), but the methodology of sampling points and field measurements should be corrected. At this moment, the results are significantly affected by each study site and their local conditions. In other studies, Compound Topographic Index (CTI) (Higginbottom et al., 2018), Soil Wetness Index (SWI) (Murphy, Ogilvie, \& Arp, 2009) from LiDAR data, and Empirical Standardized Soil Moisture Index (ESSMI) (Carrão et al., 2016) from multispectral satellite imagery that could be used for developing current research show good results at high-resolution soil wetness mapping.

Results from principal component analysis show similarities with linear regression models. First of all, there is a close negative relationship between soil moisture and normalized height models (higher in $25 \mathrm{~m}$ and lower in $10 \mathrm{~m}$ resolutions) meaning that lowest areas in a local terrain also can show wet areas. Results show that the raw data in summer months is not appropriate for soil moisture identification as different crops show different values. Data should be analysed (classified) by the type of crops and usually there is not visible water accumulation on the fields, whereas the best correlation is in scenes from April and October before and after active vegetation period. Results show the time frame on which imagery data it would be necessary to focus on to develop this research (Figure 1).

Results of this study suggest that there is much to implement for future development of this research. First of all, implementing more study sites and more sample plots in each study site is necessary for objective data analysis; secondly, focusing on the percentage of soil moisture as the main indicator of wet areas, using more measurements in every sample plot and calculating average; thirdly, expanding research and calculating specific moisture indexes, which have shown good results in other studies: Compound Topographic Index (CTI), Soil Wetness Index (SWI) and Empirical Standardized Soil Moisture Index (ESSMI).

\section{Conclusions}

To use old soil maps, developed more than 40 years ago, in order to get an overview about soil wetness conditions is inappropriate. Soil sub-types over the time have changed, mainly reduced humidity 
conditions have been observed. As technologies like LiDAR and satellite imagery are rapidly developing, different studies show that it is possible to define wet areas with high accuracy.

The results from this study are not as high as expected and other studies have shown, but two of calculated indices show statistically significant results and with better study site and sample plot design it should be possible to obtain better results for usage in wet soil prediction models.

\section{References}

1. Alparone, L., Baronti, S., Garzelli, A., \& Nencini, F. (2004). A global quality measurement of pansharpened multispectral imagery. IEEE Geoscience and Remote Sensing Letters, 1(4), 313-317. DOI: 10.1109/LGRS.2004.836784.

2. Bellian, J.A., Kerans, C., \& Jennette, D.C. (2005). Digital outcrop models: applications of terrestrial scanning lidar technology in stratigraphic modeling. Journal of sedimentary research, 75(2), 166-176. DOI: $10.2110 /$ jsr.2005.013.

3. Beven, K., \& Germann, P. (1982). Macropores and water flow in soils. Water resources research, 18(5), 1311-1325. DOI: 10.1029/WR018i005p01311.

4. Böhner, J., Koethe, R., Conrad, O., Gross, J., Ringeler, A., \& Selige, T. (2001). Soil regionalisation by means of terrain analysis and process parameterisation. Soil classification, (7), 213.

5. Böhner, J., \& Selige, T. (2006). Spatial prediction of soil attributes using terrain analysis and climate regionalisation.

6. Burt, T., \& Butcher, D. (1986). Stimulation from simulation? A teaching model of hillslope hydrology for use on microcomputers. Journal of Geography in Higher Education, 10(1), 23-39.

7. Carrão, H., Russo, S., Sepulcre-Canto, G., \& Barbosa, P. (2016). An empirical standardized soil moisture index for agricultural drought assessment from remotely sensed data. International journal of applied earth observation and geoinformation, 48, 74-84. DOI: 10.1016/j.jag.2015.06.011.

8. Case, B.S., Meng, F.R., \& Arp, P.A. (2005). Digital elevation modelling of soil type and drainage within small forested catchments. Canadian journal of soil science, 85(1), 127-137. DOI: 10.4141/S04-008.

9. Christensen, N.L., Bartuska, A.M., Brown, J.H., Carpenter, S., D’Antonio, C., Francis, R., \& Woodmansee, R.G. (1996). The Report of the Ecological Society of America Committee on the Scientific Basis for Ecosystem Management. Ecological Applications, Vol. 6, Iss. 3, pp. 665-691. DOI: 10.2307/2269460.

10. Dassot, M., Constant, T., \& Fournier, M. (2011). The use of terrestrial LiDAR technology in forest science: application fields, benefits and challenges. Annals of forest science, 68(5), 959-974. DOI: 10.1007/ s13595-011-0102-2.

11. Deilami, K., \& Hashim, M. (2011). Very high resolution optical satellites for DEM generation: A review. European Journal of Scientific Research, 49(4), 542-554.

12. Drusch, M., Del Bello, U., Carlier, S., Colin, O., Fernandez, V., Gascon, F., ... \& Meygret, A. (2012). Sentinel-2: ESA's optical high-resolution mission for GMES operational services. Remote sensing of Environment, 120, 25-36. DOI: 10.1016/j.rse.2011.11.026.

13. Godfray, H.C.J., Beddington, J.R., Crute, I.R., Haddad, L., Lawrence, D., Muir, J.F., \& Toulmin, C. (2010). Food security: the challenge of feeding 9 billion people. Science. 327 (5967), 812-818. DOI: 10.1126/ science. 1185383 .

14. Higginbottom, T.P., Field, C.D., Rosenburgh, A.E., Wright, A., Symeonakis, E., \& Caporn, S.J.M. (2018). High-resolution wetness index mapping: A useful tool for regional scale wetland management. Ecological Informatics, 48, 89-96. DOI: 10.1016/j.ecoinf.2018.08.003.

15. Immitzer, M., Vuolo, F., \& Atzberger, C. (2016). First experience with Sentinel-2 data for crop and tree species classifications in central Europe. Remote Sensing, 8(3), 166. DOI: 10.3390/rs8030166.

16. Ivanovs, J., \& Lupikis, A. (2018). Identification of wet areas in forest using remote sensing data. DOI: 10.15159/AR.18.192.

17. Kasparinskis, R., \& Kārkliņš, A. (2018). Augsnes sega (Soil blanket). In O. Nikodemus (Eds.). Latvija: zeme, daba, tauta, valsts (pp. 332-364). Rīga, Latvijas Universitātes Akadēmiskais apgāds. (in Latvian)

18. Kārkliņš, A., Gemste, I., Mežals, H., Nikodemus, O., \& Skujāns, R. (2009). Latvijas augšņu noteicējs (Taxanomy of Latvia soils). Jelgava, LLU. (in Latvian)

19. McCoy, M.D., Asner, G.P., \& Graves, M.W. (2011). Airborne lidar survey of irrigated agricultural landscapes: an application of the slope contrast method. Journal of Archaeological Science, 38(9), 21412154. DOI: $10.1016 /$ j.jas.2011.02.033.

20. Minasny, B., \& McBratney, A.B. (2016). Digital soil mapping: A brief history and some lessons. Geoderma, 264, 301-311. DOI: 10.1016/j.geoderma.2015.07.017. 
21. Mitchell, J.K., \& Soga, K. (2005). Fundamentals of soil behavior Vol. 3, Hoboken, NJ: John Wiley \& Sons.

22. Moskal, L.M., Erdody, T., Kato, A., Richardson, J., Zheng, G., \& Briggs, D. (2009). Lidar applications in precision forestry. Proceedings of Silvilaser, 154-163.

23. Murphy, P.N.C., Ogilvie, J., \& Arp, P. (2009). Topographic modelling of soil moisture conditions: a comparison and verification of two models. European Journal of Soil Science, 60(1), 94-109. DOI: 10.1111/j.1365-2389.2008.01094.X.

24. O'Callaghan, J.F., \& Mark, D.M. (1984). The extraction of drainage networks from digital elevation data. Computer vision, graphics, and image processing, 28(3), 323-344. DOI: 10.1016/S0734189X(84)80011-0.

25. Pearsall, W.H. (1950). The investigations of wet soils and its agricultural implications. Empire Journal of Experimental Agriculture, 18, 289-298.

26. Pettorelli, N., Vik, J.O., Mysterud, A., Gaillard, J.M., Tucker, C.J., \& Stenseth, N.C. (2005). Using the satellite-derived NDVI to assess ecological responses to environmental change. Trends in ecology \& evolution, 20(9), 503-510. DOI: 10.1016/j.tree.2005.05.011.

27. Plantureux, S., Peeters, A., \& McCracken, D. (2005). Biodiversity in intensive grasslands: Effect of management, improvement and challenges. Agronomy research, 3(2), 153-164.

28. Schwarz, B. (2010). LIDAR: Mapping the world in 3D. Nature Photonics, 4(7), 429. DOI: 10.1038/ nphoton.2010.148.

29. Sørensen, R., \& Seibert, J. (2007). Effects of DEM resolution on the calculation of topographical indices: TWI and its components. Journal of Hydrology, 347(1-2), 79-89. DOI: 10.1016/j.jhydrol.2007.09.001.

30. Tester, M., \& Langridge, P. (2010). Breeding technologies to increase crop production in a changing world. Science. 327 (5967), 818-822. DOI: 10.1126/science.1183700.

31. Tilman, D., Cassman, K.G., Matson, P.A., Naylor, R., \& Polasky, S. (2002). Agricultural sustainability and intensive production practices. Nature. 418 (6898), 671. DOI: 10.1038/nature01014.

32. Vereecken, H., Huisman, J.A., Bogena, H., Vanderborght, J., Vrugt, J.A., \& Hopmans, J.W. (2008). On the value of soil moisture measurements in vadose zone hydrology: A review. Water resources research, 44(4). DOI: 10.1029/2008WR006829.

33. Wang, L., \& Liu, H. (2006). An efficient method for identifying and filling surface depressions in digital elevation models for hydrologic analysis and modelling. International Journal of Geographical Information Science, 20(2), 193-213. DOI: 10.1080/13658810500433453.

34. Zinko, U., Seibert, J., Dynesius, M., \& Nilsson, C. (2005). Plant species numbers predicted by a topographybased groundwater flow index. Ecosystems, 8(4), 430-441. DOI: 10.1007/PL00021513. 